DOI: 10.14807/ijmp.v10i4.998

\title{
SALES FORECASTING IN A MECHANICAL COMPONENT MANUFACTURER: COMPARISON BETWEEN MONTE CARLO SIMULATION AND TIME SERIES ANALYSIS
}

\author{
Kevin William Matos Paixão \\ Instituto Federal de São Paulo - Campus Suzano, Brazil \\ E-mail: kevinwilliamp@gmail.com \\ Adriano Maniçoba da Silva \\ Instituto Federal de São Paulo - Campus Suzano, Brazil \\ E-mail: adrianoms@ifsp.edu.br
}

Submission: 01/31/2019 Accept: 02/10/2019

\section{ABSTRACT}

Organizations today are required to be prepared for future situations. This preparation can generate a significant competitive advantage. In order to maximize benefits, several companies are investing more in techniques that simulate a future scenario and enable more precise and assertive decision making. Among these techniques are the sales forecasting methods. The comparison between the known techniques is an important factor to increase the assertiveness of the forecast. The objective of this study was to compare the sales forecast results of a mechanical components manufacturing company obtained through five different techniques, divided into two groups, the first one, which uses the fundamentals of the time series, and the second one is the Monte Carlo simulation. The following prediction methods were compared: moving average, weighted moving average, least squares, holt winter and Monte Carlo simulation. The results indicated that the methods that obtained the best performance were the moving average and the weighted moving average attaining $94 \%$ accuracy.

Keywords: sales forecast, Monte Carlo simulation, mechanical components 
DOI: 10.14807/ijmp.v10i4.998

\section{INTRODUCTION}

Technological evolution and management techniques and methods development will make the market competition fierce. The simple exchange system of products and services that was once the basic essence of the market, has given way to a crowded and contested environment where only those companies that differentiate themselves from competitors will stand out (MCKENNA, 2005).

Achieving this advantage is a major challenge, since the management sectors use strategies and conduct planning based on market analysis as well as competitors and customers. All this effort is carried out in order to increase the company's competitiveness.

A well-structured company should not only concern itself with current trends but make decisions aiming at medium and long-term results. However, in order to achieve these results and become more competitive, several companies use techniques that can estimate a foreseeable future. These techniques are known as demand forecasting.

For Haack and Rodrigues (2018), predicting demand means estimating future market positions and anticipating the consumer's response to their product. This trick uses two different methods on its procedure. The first is the qualitative method which consists of a forecast made by experts based on their own analysis. The second is the quantitative method, which consists of a numerical estimate generated through historical analysis. This model can be made through different mathematical procedures.

Within a decision-making environment, demand forecasting with a higher level of accuracy can benefit several sectors of an organization. According to Werner and Ribeiro (2006), the selection of which technique a company should use in its forecasts must take into account the degree of complexity of the multiple manufacturing sectors, thus seeking greater accuracy.

A systematic search with the terms "sales forecast" and "forecast demand" was performed in the SPELL database that resulted in nine articles dealing with these issues. Some papers compared demand forecasting techniques based on time series. However, no study compared the efficacy of these techniques with the Monte Carlo simulation. 
The purpose of this study was to compare demand forecasting results with the sales made by an electronic component manufacturer using time series methods and Monte Carlo simulation.

The work was structured in six sections: introduction, literature review, methodology, results, discussion and conclusion.

\section{LITERATURE REVIEW}

\subsection{Demand Forecasting System}

In order to define the best demand forecasting system to use, Pellegrini and Fogliatto (2001) point out that three basic conditions must be taken into account: the availability of historical information, the possibility of transforming information into data, and the assumption patterns repeating themselves. These are the assumptions used to select a demand forecasting method.

A time series, or "historical series" as it is also known, is defined by a series of information (numerical values) obtained in a regular space of time. These numbers can be obtained by periodically observing the event under study or by counting. According to Pellegrini and Fogliatto (2001), the measurement units of this element and the size of the observed period have influence in the choice of the mathematical procedure to be used.

According to Makridakis (1998) and Moreira (2001), a time series has four known components: The average component, which is the simplest behavior that a series can have, which occurs when the values of a series oscillate between constant an average value; Component trend, which has behavior indicating whether the series will have growth or reduction; Seasonal component, which is based on the lack or excess demand of certain items always in very specific periods. Following the reasoning of Morettin and Toloi (1987) seasonal products can also be called annual or stationary components; Cyclical component, which, according to Moreira (2001), are fluctuations of general order and with varying frequency; and Random component, being an anomaly caused by events of known or unknown order.

According to Pellegrini and Fogliatto (2001), the results have two basic elements that are: Horizon, which can be defined as the temporal distance that the results allow to visualize; and the second element is an interval, which defines the frequency at which new forecasts are prepared. 
Within the quantitative methodology of demand forecasting, we can find two distinct systems of mathematical models, which according to Armstrong (2001) are: System of causal methods, in their composition causal variables are estimated and are related to estimates of independent variables; Extrapolation system, whose principle of operation lies in the assumption of constant patterns and stationarity of the data (historical series) used in the process, i.e., this system predicts future patterns through the relation of values existing in the past.

According to the reasoning of Lemos (2006) the extrapolation system is divided into two methods. And these are: Open Mathematical Modeling Methods, which are characterized by specific methods, which consider characteristics of each business within the historical series. Although this is a very accurate method, its use requires high investment to identify specific components; and Methods with Fixed Mathematical Models, which are simple, low cost methods, since they have fixed equations that consider the basic factors of the historical series. This method is recommended for short-term forecasts and environments undergoing constant change.

\subsection{Forecasting methods}

\subsubsection{Moving Average (MA)}

According to Tubino (2009), the main characteristic using the moving average as a mathematical procedure within the forecast of demand is the combination of high and low values, thus generating a forecast with little variability. The operation of this mathematical procedure consists of dividing the sum of values obtained during a given period by the number of periods. Its mathematical expression is exposed as follows:

$$
M_{p}=\frac{P_{1}+P_{2}+P_{3}+\cdots P_{n}}{n}
$$

$M p=$ average (forecast)

$P 1=$ Period 1

$P 2=$ Period 2

$P 3=$ Period 3

P4= Period 4

$P n=$ Possible numerical values 
ISSN: 2236-269X

DOI: 10.14807/ijmp.v10i4.998

$n=$ Number of values that were summed

This forecasting method is called the moving average because, at the end of a period, the actual result obtained in the calculation is added and the oldest period is extracted. In this way, the forecast remains within the real trend. According to Davis, Aquilan and Chase, (2001), this method has low accuracy when dealing with seasonal products. To solve this problem, it is common to use a variation of this procedure, called the weighted moving average.

\subsubsection{Weighted Moving Average (WMA)}

This procedure is similar to the simple moving average formula presented above, the difference being that weights are used to determine the influence of the periods on the final result.

$$
M p=\frac{\left(X_{1}^{*} P_{1}\right)+\left(x_{2}{ }^{*} P_{2}\right)+\cdots(x n * P n)}{x_{1}+X_{2}+\cdots \times n}
$$

$M_{p}=$ Average (forecast))

$P_{1}=$ Period 1

$P_{2}=$ Period 2

$P_{n}=$ infinite values

$x_{1}=$ Ponderation 1

$x_{2}=$ Ponderation 2

$x_{n}=$ possible number of ponderations

In this model, the principle of replacing the last period with the most recent one, which has already been completed, remains. Tubino (2009) states that the disadvantage of this procedure lies in the fact that it is necessary to have a specialized opinion to propose the weighting values.

\subsubsection{Holt Winter Method}

The Holt winter method, according to Chopra and Meindl (2003), consists of a system of estimating demand components based on the already existing ones in the time series. Basically this is also an exponential smoothing method in which the time series is decomposed into its components, and they are weighted relative to the time 
DOI: 10.14807/ijmp.v10i4.998

distance. This weighting is applied in the forecast, maintaining the pattern of the time series components.

The decomposition can take two different forms; Multiplicative and Additive and what determines this form is the nature of the demand. To measure the forecasts through Holt winter the formulas in Table 1 are used:

Table 1: - Holt Winter Formulas

\begin{tabular}{|c|c|c|}
\hline Component & Multiplicative & Additive \\
\hline Level & $L=\alpha * \frac{Y}{S_{T-S}}+(1-\alpha) *\left(L_{T-1}+B_{T-1}\right)$ & $L=\alpha *\left(Y_{T}-S_{t-S}\right)+(1-\alpha) *\left(L_{t-1}+B_{t-1}\right)$ \\
\hline Tendency & $b_{t}=\beta *\left(L_{t}-L_{t-1}\right)+(1-\beta) * B_{t-1}$ & $b_{t}=\beta *\left(L_{t}-L_{t-1}\right)+(1-\beta) * B_{t-1}$ \\
\hline Seasonality & $S_{t}=\gamma * \frac{Y_{t}}{L_{t}}+(1-\gamma) * S_{T-S}$ & $S_{t}=\gamma *\left(Y_{t}-L_{t-1}\right)+(1-\gamma) * S_{T-S}$ \\
\hline Forecast & $F_{t+m}=\left(L_{T}+b_{T-M}\right) * S_{t-s+m}$ & $F_{t+m}=L_{t}+b_{t-m}+S_{t-s+m}$ \\
\hline
\end{tabular}

Source: Adapted from Chopra e Meindl (2003)

Where:

s - Length of seasonality

Lt - Series Level

bt - Trend

St - Seasonal component

$\mathrm{Fm}+\mathrm{t}$ - Forecast for the period $\mathrm{m}$ ahead

Yt - Observed value

$\alpha, \beta$ and $y$-Smoothing exponential parameters, level, trend and seasonality, respectively.

\subsubsection{Least Squares Estimate (LSE)}

Helene (2006) states that the least squares estimate is the most popular method and one of the most efficient in the treatment of experimental data. Briefly, this procedure consists in the search for a mathematical function that best fits in a series of points plotted in a Cartesian plane. The main premise in this process is the principle of minimizing the square of the sum of the differences (error) between the estimated value and the observed value. 


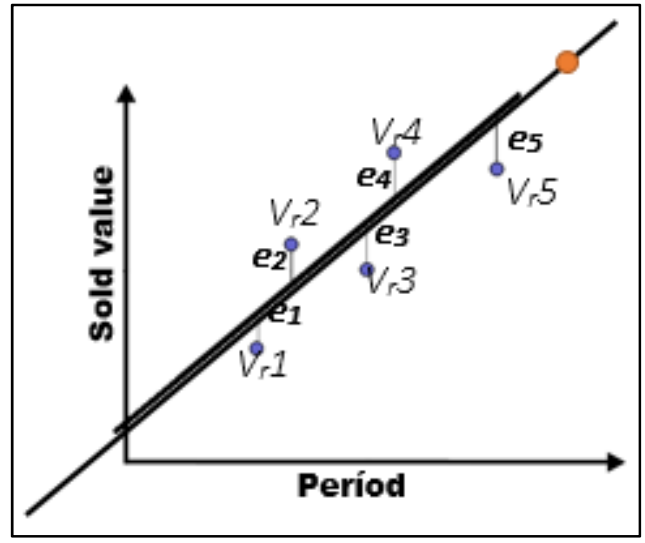

Figure 1: Line of representation of points Source: The Authors

$\mathrm{e}_{1}=$ Error 1

$\mathrm{e}_{2}=$ Error 2

$\mathrm{e}_{3}=$ Error 3

$\mathrm{e}_{4}=$ Error 4

$e_{n}=$ Error 5

$\mathrm{V}_{\mathrm{r}} 1=$ Real sales value on Period 1

$V_{r} 2=$ Real sales value on Period 2

$V_{r} 3=$ Real sales value on Period 3

$V_{\mathrm{r}} 4=$ Real sales value on Period 4

$V_{\mathrm{r}} 5=$ Real sales value on Period 5

$\mathrm{P}=$ Forecast for period 6

According to Hair et al. (2009), the linear regression procedure estimates the degree of association between a dependent variable (sold values) and an independent variable (periods), and thereby determines a correlation (trend) between them.

\subsubsection{Monte Carlo Simulation}

Monte Carlo Simulation is a mathematical tool of operational research capable of creating a simulation of stochastic order scenarios, that is, scenarios that depend on a random and unpredictable variable. This method was named during World War II during the Manhattan project, making reference to the city of Monaco known at that time as the capital of gambling. Its principle of operation is statistical, where through a 
random sequence of numbers an event simulation is generated in which the average behavior of the variables is the ideal estimated solution. With this Fernandes (2005) divides the Monte Carlo process into 3 phases; First, establish a probability distribution (random variables of the problem) and correlate them with random numbers that will simulate the random variable (random number generator); The second, sample again and again (sampling techniques); The third, calculate the average behavior of the samples and the standard deviation thus obtaining the ideal estimated solution.

According to Donatelli and Konrath (2005) the best application for the Monte Carlo simulation is in mathematical systems that do not allow an analytical solution due to the unpredictability of the information, since it is a technique with high effectiveness in random statistical sampling.

Garcia, Lustosa and Barros (2010) apply the Monte Carlo simulation to predict the cost of production of industrial companies, using 28 entities, and generating 5600 simulations for them. Mendes, Silva and Kawamoto Júnior (2016) used Monte Carlo simulation to analyze the variability in capacity caused by human behavior.

In addition, Monte Carlo simulation is applied to a process of risk analysis, where it points out important aspects in the creation of any simulation: the choice of an adequate level of confidence and the application of empirical distribution in a coherent way. In addition, it evidences the fact that a considerable sample must be contained to obtain feasible results.

\subsection{Average Absolute Percentage Error}

To evaluate the performance of a forecasting technique, it is necessary to compare the predicted data with reality. In agreement with Heizer and Render (2004), this mathematical procedure consists of the average of the absolute difference between the predicted values and the actual values expressed as a percentage of the values reached. In order to obtain this result it is necessary to go through two stages.

1st stage: Obtaining the individual percentage error (PE)

$$
E P=\frac{(V r 1-P 1)}{V r 1} * 100
$$

$E P=$ Percentual Error

Vr1 = Real value obtained in the first period in which it was intended to predict 
DOI: 10.14807/ijmp.v10i4.998

$P 1=$ previsão para $\operatorname{Vr1}$

2nd stage: Obtention of the Absolute average percentage error (AAPE)

$$
E M P=\frac{|E P 1|+|E P 2| \ldots|E P n|}{n} * 100
$$

$E M P=$ Average Percent Error

$|E P 1|=$ Percentage error module obtained in the first forecasting period

|EP2 | = Percentage error module obtained in the second forecast period

$|E P n|=$ percentage error module obtained in the numerous forecast periods

$n=$ amount of PE used in the sum

\section{METHODOLOGY}

This study used the case study methodology applied at a company in the Alto Tietê region of the state of São Paulo, located in the city of Suzano. Its main product is a specific mechanical component. Data on components sold per month were obtained. The sample collected represents 96 months, from September 2011 to August 2018, totaling seven years. The forecast models were analyzed with 84 months and the last 12 months were used to analyze the prediction performance. The collected data used can be visualized in Table 2.

Table 2: Data collected

\begin{tabular}{|l|c|c|c|c|c|c|c|}
\hline & $2010 / 11$ & $2011 / 12$ & $2012 / 13$ & $2013 / 14$ & $2014 / 15$ & $2015 / 16$ & $2016 / 17$ \\
\hline September & 3.627 .157 & 3.891 .218 & 3.329 .907 & 3.602 .552 & 3.112 .388 & 3.073 .420 & 3.498 .121 \\
\hline October & 3.460 .229 & 3.772 .815 & 3.411 .403 & 3.654 .776 & 3.743 .145 & 3.299 .349 & 3.281 .806 \\
\hline November & 3.551 .704 & 3.589 .642 & 3.573 .171 & 3.378 .208 & 3.384 .299 & 3.260 .945 & 3.337 .972 \\
\hline December & 2.582 .564 & 2.782 .598 & 2.438 .752 & 2.526 .394 & 2.798 .412 & 2.335 .088 & 2.990 .215 \\
\hline January & 3.205 .249 & 3.259 .099 & 2.987 .974 & 3.206 .115 & 2.807 .163 & 3.118 .495 & 3.467 .309 \\
\hline February & 3.278 .786 & 3.251 .362 & 3.515 .425 & 3.009 .833 & 3.113 .183 & 2.921 .120 & 3.246 .857 \\
\hline March & 4.212 .786 & 3.293 .631 & 3.296 .673 & 3.056 .192 & 3.682 .002 & 3.532 .763 & 3.717 .665 \\
\hline April & 3.686 .997 & 3.458 .653 & 3.743 .282 & 3.239 .210 & 3.307 .913 & 3.086 .425 & 2.963 .617 \\
\hline May & 3.472 .292 & 3.170 .491 & 3.677 .122 & 3.301 .557 & 3.250 .123 & 3.377 .096 & 3.454 .247 \\
\hline June & 3.514 .847 & 2.824 .897 & 3.385 .928 & 2.577 .480 & 3.035 .108 & 3.184 .060 & 2.690 .163 \\
\hline July & 3.675 .996 & 3.369 .053 & 3.521 .605 & 3.288 .554 & 3.205 .254 & 3.488 .280 & 3.783 .167 \\
\hline August & 3.795 .276 & 3.858 .877 & 3.693 .130 & 3.163 .077 & 2.988 .775 & 3.417 .848 & 3.566 .406 \\
\hline
\end{tabular}

Thus, five forecasts were obtained each month, all of which were analyzed and compared with the previous year's sales results, using the Average Absolute Error $(\mathrm{AAE})$ as a reference.

In the Holt Winter model the following specific steps were followed: 
- 1 st Step - Demand de-seasonalization

- $2^{\circ}$ Step- Estimate of level and trend with linear regression applied to seasonally adjusted demand as a function of the period;

- $3^{\circ}$ Step- Estimation of seasonality factors;

- $4^{\circ}$ Step - Application of the estimation in the demands to obtain the forecast;

- In the Monte Carlo method, the following steps were followed:

- 1st Step -Testing adherence to the demand seasonal demand adjusted and without a complete trend (creation of the PDF).

- 2 nd Step - Calculation of the number of necessary simulations.

- 3rd Step - Generation of 50240 simulations for seasonally adjusted demand.

- $4^{\circ}$ Step- Application of the seasonality and trend factor of each month of the year in the average of all the values generated in the simulations

In order to perform the cited procedures, computational resources of the Arena and Calc software were used. The execution of this process served the basic purpose of scientific research that according to Severino (2017) consists in the knowledge of an object in its primary sources and foundations. The term "object" mentioned above can be attributed all mathematical content and the mechanics of data analysis that were explored in this article.

\section{RESULTS}

\subsection{Time Series}

The results of time series forecasting methods can be seen in Table 3 .

Table 3: Time series final results

\begin{tabular}{|c|c|c|c|c|}
\hline $\begin{array}{c}\text { Forecasting } \\
\text { Method }\end{array}$ & MA & WMA & Holt Wilter & LSE \\
\hline September & 3.447 .823 & 3.412 .556 & 3.234 .951 & 3.127 .791 \\
\hline October & 3.517 .646 & 3.459 .259 & 3.302 .390 & 3.353 .295 \\
\hline November & 3.439 .420 & 3.406 .868 & 3.228 .014 & 3.226 .926 \\
\hline December & 2.636 .289 & 2.675 .366 & 2.477 .883 & 2.734 .517 \\
\hline January & 3.150 .201 & 3.193 .963 & 2.959 .670 & 3.196 .509 \\
\hline February & 3.190 .938 & 3.182 .030 & 2.994 .540 & 3.025 .436 \\
\hline March & 3.541 .673 & 3.561 .694 & 3.324 .966 & 3.452 .849 \\
\hline April & 3.355 .157 & 3.262 .376 & 3.143 .648 & 2.876 .590 \\
\hline
\end{tabular}


DOI: 10.14807/ijmp.v10i4.998

\begin{tabular}{|c|c|c|c|c|}
\hline May & 3.386 .133 & 3.396 .245 & 3.179 .335 & 3.376 .429 \\
\hline June & 3.030 .355 & 2.986 .956 & 2.840 .817 & 2.729 .420 \\
\hline July & 3.475 .987 & 3.525 .616 & 3.263 .920 & 3.510 .789 \\
\hline August & 3.497 .627 & 3.503 .725 & 3.278 .720 & 3.172 .909 \\
\hline Average & 3.305 .771 & 3.297 .221 & 3.102 .404 & 3.148 .622 \\
\hline
\end{tabular}

Source: The authors

In the execution of the mathematical procedure of the weighted moving average, according to the content exposed in the bibliographic review, an executive from the company was consulted, to collect the data to carry out the weighting of the time series. Table 4 presents the weighting and its justifications:

Table 4: Weights used

\begin{tabular}{|c|c|c|c|}
\hline Year & Weighing & $\begin{array}{c}\text { Justification } \\
\text { Influence on } \\
\text { forecast }\end{array}$ \\
\hline 1 & 2 & Promising market, growing economy for the old period. & $8 \%$ \\
\hline 2 & 3 & $\begin{array}{c}\text { Increasing automotive market, and stable post-election } \\
\text { period. }\end{array}$ & $12 \%$ \\
\hline 3 & 3 & IPI reduction policies kept the car market stable. & $12 \%$ \\
\hline 4 & 2 & Fall in growth and retraction in the industrial market. & $8 \%$ \\
\hline 5 & 3 & $\begin{array}{c}\text { Close period and high drop in the automotive and } \\
\text { industrial market. }\end{array}$ & $12 \%$ \\
\hline 6 & 5 & $\begin{array}{c}\text { Economic retraction in the country driven by political } \\
\text { crisis. }\end{array}$ & $20 \%$ \\
\hline 7 & 7 & $\begin{array}{c}\text { Closest period with recessive economy and market for } \\
\text { investment }\end{array}$ & $28 \%$ \\
\hline
\end{tabular}

Source: The authors

Also obtained through the least squares estimate were dispersion diagrams with trend lines. Figure 2 presents two examples.
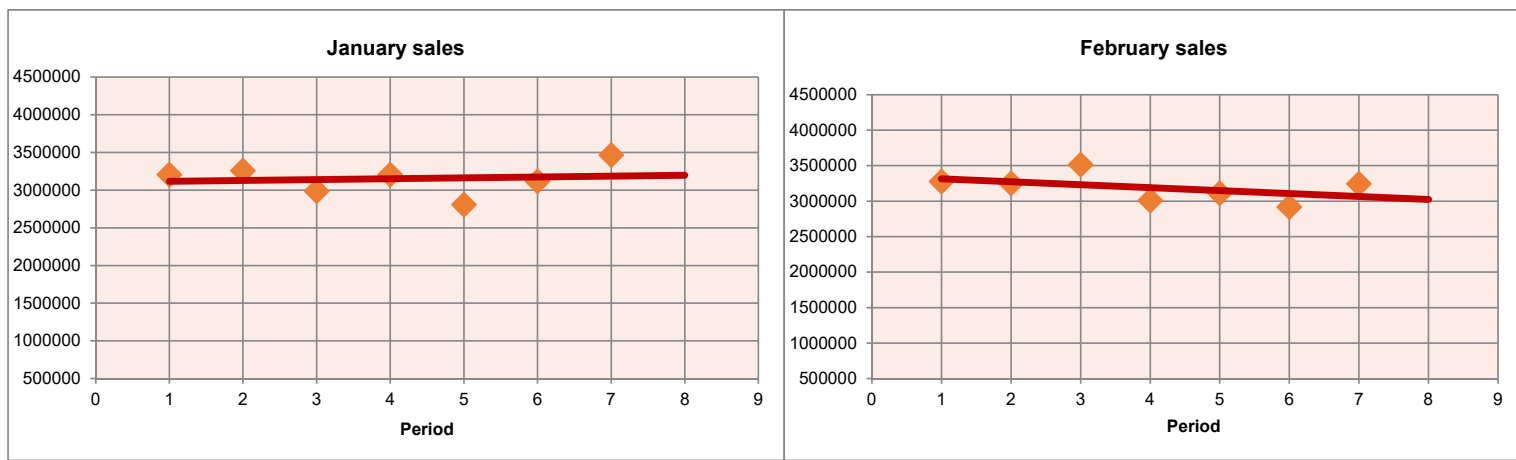

Figure 2: Trends dispersion diagrams Source: The authors

\subsection{Monte Carlo Simulation}

\subsubsection{Adherence test}


The adherence test was performed on the Input Analyzer module of the Arena software. With the 84 observations representing the sales in the last 7 years (Table 2) the tests performed by the software were the Chi-Square and Kolmogorov-Smirnov tests, both of which showed a p-value greater than 0.05 which guaranteed good adherence to the tested distribution. After this, a simple frequency distribution histogram was created, it contained 10 classes whose interval began in the value $2,335,088$ and finished in the value 4,212,786, each interval had a amplitude in the value of 208.633 which resulted in a maximum frequency of 24 entities and a minimum of 1 entity. The PDF generated through this distribution generated a normal curve in the bell format.

\subsubsection{Number of simulations required}

In order to calculate a number of necessary simulations based on a percentage of error, Harrel et al. (2004) propose the following equation:

$$
N^{\prime}=\left[\frac{(1,96) * S}{(1+r e) * X}\right]^{2}
$$

$N^{\prime}=$ is the number of replications

$S=I S$ the standard deviation of the data collected

$X=I s$ the average of the data collected

$r e=I t$ is the percentage error defined by the user

To perform the simulation, the data from Table 5 were used to calculate the number of replications:

Table 5: Data for Replications calculations

\begin{tabular}{|c|c|r|r|}
\hline S & $\mathbf{X}$ & $\mathbf{R e}$ & $\mathbf{N}^{\prime}$ \\
\hline 350096,53 & 3.305 .771 & $9 \%$ & 50240 \\
\hline \multicolumn{4}{|c}{ Source: The authors }
\end{tabular}

\subsubsection{Histogram and confidence interval}

With the generated PDF and the number of replications defined, the simulations were generated obtaining the histogram represented in Figure 3.

Table 6: Sample Size

\begin{tabular}{|l|l|} 
Sample Size & 50240 \\
\hline Maximum & 4663990 \\
\hline Mimimum & 1855230 \\
\hline
\end{tabular}


ISSN: 2236-269X

DOI: 10.14807/ijmp.v10i4.998

\begin{tabular}{|l|l|}
\hline Amplitude & 125339,10714 \\
\hline No. of intervals & 224 \\
\hline Average & 3251420,263 \\
\hline Pattern deviation & 837452,3166
\end{tabular}

Source: The authors

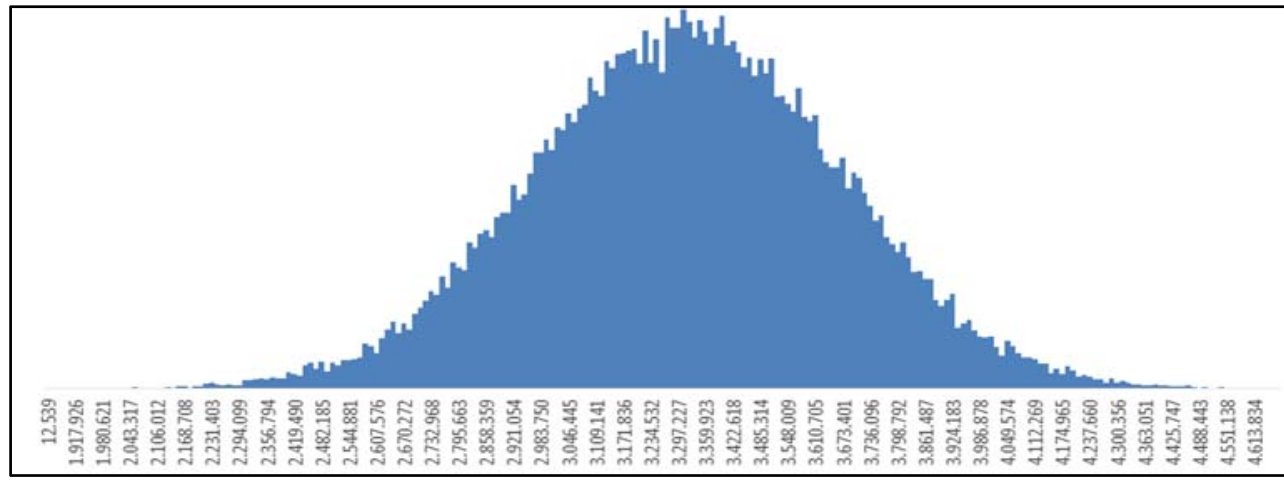

Figure 3: Simulation histogram Source: The authors

With this, we can calculate confidence interval, presented in Table 7, using the following formulas:

$$
\begin{aligned}
& \text { upper Limit }=X+\frac{(1,96) * S}{\sqrt{N^{\prime}}} \quad \text { Lower Limit }=X-\frac{(1,96) * S}{\sqrt{N^{\prime}}} \\
& N^{\prime}=\text { is the number of replications } \\
& S=\text { is the standard deviation of the SIMULATED data } \\
& X=\text { The average of the SIMULATED data } \\
& r e=I t \text { is the percentage error defined by the user }
\end{aligned}
$$

\subsubsection{Monte Carlo simulation results}

Using the methodology presented, the results of Monte Carlo simulation were presented in Table 8.

Table 8: Results of Monte Carlo simulation

\begin{tabular}{|c|c|}
\hline Forecasting Method & Monte Carlo Simulation \\
\hline September & 3.281 .542 \\
\hline October & 3.174 .062 \\
\hline November & 3.527 .835 \\
\hline December & 3.340 .486 \\
\hline January & 3.380 .639 \\
\hline February & 3.024 .965 \\
\hline March & 3.478 .119 \\
\hline April & 3.498 .931 \\
\hline
\end{tabular}


DOI: 10.14807/ijmp.v10i4.998

\begin{tabular}{|c|c|}
\hline May & 3.452 .617 \\
\hline June & 3.528 .091 \\
\hline July & 3.452 .605 \\
\hline August & 2.652 .435 \\
\hline Average & 3.316 .027 \\
\hline
\end{tabular}

Sourche: The authors

\subsection{Analysis and comparison with the last period}

With the result of the last period it was possible to compare the methods as can be seen in Table 9.

Table 9: Comparison of forecasting methods

\begin{tabular}{|c|c|c|c|c|c|c|}
\hline Forecasting Method & September & October & November & December & January & February \\
\hline MA & 3.447 .823 & 3.517 .646 & 3.439 .420 & 2.636 .289 & 3.150 .201 & 3.190 .938 \\
\hline WMA & 3.412 .556 & 3.459 .259 & 3.406 .868 & 2.675 .366 & 3.193 .963 & 3.182 .030 \\
\hline Holt Wilter & 3.234 .951 & 3.302 .390 & 3.228 .014 & 2.477 .883 & 2.959 .670 & 2.994 .540 \\
\hline LSE & 3.127 .791 & 3.353 .295 & 3.226 .926 & 2.734 .517 & 3.196 .509 & 3.025 .436 \\
\hline Monte Carlo Simulation & 3.281 .542 & 3.174 .062 & 3.527 .835 & 3.340 .486 & 3.380 .639 & 3.024 .965 \\
\hline 8th year oficial result & 3.360 .811 & 3.371 .101 & 3.476 .368 & 2.741 .386 & 3.533 .791 & 3.701 .944 \\
\hline \multicolumn{7}{|c|}{ Error analysis } \\
\hline MA Error & -87.012 & -146.545 & 36.948 & 105.097 & 383.590 & 511.006 \\
\hline WMA Error & -51.745 & -88.158 & 69.500 & 66.020 & 339.828 & 519.914 \\
\hline Holt Wilter Error & 125.860 & 68.711 & 248.354 & 263.503 & 574.121 & 707.404 \\
\hline LSE Error & 233.020 & 17.806 & 249.442 & 6.869 & 337.282 & 676.508 \\
\hline Monte Carlo Error & 79.269 & 197.039 & -51.467 & -599.100 & 153.152 & 676.979 \\
\hline \multicolumn{7}{|c|}{ Absolute Error analysis } \\
\hline MA Absolute Error & 87.012 & 146.545 & 36.948 & 105.097 & 383.590 & 511.006 \\
\hline WMA Absolute Error & 51.745 & 88.158 & 69.500 & 66.020 & 339.828 & 519.914 \\
\hline Holt Winter Absolute Error & 125.860 & 68.711 & 248.354 & 263.503 & 574.121 & 707.404 \\
\hline LSE Absolute Error & 233.020 & 17.806 & 249.442 & 6.869 & 337.282 & 676.508 \\
\hline Monte Carlo Absolute Error & 79.269 & 197.039 & 51.467 & 599.100 & 153.152 & 676.979 \\
\hline \multicolumn{7}{|c|}{ Percentual error analysis } \\
\hline EMP MA & $-3 \%$ & $-4 \%$ & $1 \%$ & $4 \%$ & $11 \%$ & $14 \%$ \\
\hline EMP WMA & $-2 \%$ & $-3 \%$ & $2 \%$ & $2 \%$ & $10 \%$ & $14 \%$ \\
\hline EMP Holt Winter & $4 \%$ & $2 \%$ & $7 \%$ & $10 \%$ & $16 \%$ & $19 \%$ \\
\hline EMP LSE & $7 \%$ & $1 \%$ & $7 \%$ & $0 \%$ & $10 \%$ & $18 \%$ \\
\hline EMP Monte Carlo & $2 \%$ & $6 \%$ & $-1 \%$ & $-22 \%$ & $4 \%$ & $18 \%$ \\
\hline \multicolumn{7}{|c|}{ Absolute EMP Error analysis } \\
\hline Absolute EMP Error MA & $3 \%$ & $4 \%$ & $1 \%$ & $4 \%$ & $11 \%$ & $14 \%$ \\
\hline Absolute EMP Error WMA & $2 \%$ & $3 \%$ & $2 \%$ & $2 \%$ & $10 \%$ & $14 \%$ \\
\hline $\begin{array}{c}\text { Absolute EMP Error Holt } \\
\text { Winter }\end{array}$ & $4 \%$ & $2 \%$ & $7 \%$ & $10 \%$ & $16 \%$ & $19 \%$ \\
\hline Absolute EMP Error MMQ & $7 \%$ & $1 \%$ & $7 \%$ & $0 \%$ & $10 \%$ & $18 \%$ \\
\hline $\begin{array}{l}\text { Absolute EMP Error Monte } \\
\text { Carlo }\end{array}$ & $2 \%$ & $6 \%$ & $1 \%$ & $22 \%$ & $4 \%$ & $18 \%$ \\
\hline
\end{tabular}


ISSN: 2236-269X

DOI: 10.14807/ijmp.v10i4.998

\section{DISCUSSION}

Analyzing the average value of the errors obtained in the five methods, it is verified that the Monte Carlo Method reaches the lowest value, "77.397" units, bringing this value in percentage form, and in comparison with the official result, this error equals $1 \%$. However, this analysis does not show the real precision needed, and may negatively influence the company's decision-making.

This low percentage of error was reached due to the consonances between the positive (more than real) and negative (less than real) differences between the expected and achieved results, i.e. there is a large amount that was predicted lower than the real. However, in other months, this quantity is supplied by a high value predicted in the rise, which mathematically balances the result.

For this reason, the absolute error analysis (using only the error value modules) was applied, so that the value of "212.334" units obtained by the method of Weighted Moving Average. This value, when taken to percentage unit reaches the house of $6 \%$. This same percentage of error was reached by the Moving Average method.

Regarding the Holt Winter and the Least Squares Estimate methods, the average absolute error rate reached was the same as the Monte Carlo, 9\%, although the monthly error values were different.

These results contradict Davis, Aquilan and Chase, (2001) statement, mentioned in the topic of bibliographic review. They claim that the mobile average method has low accuracy when applied to products that have a seasonal component.

Another objection also contradicted is that of Slack (2013), which takes as a negative point the fact that the weighted moving average method is more influenced by the most recent period, in the opinion of the authors of this work this characteristic is positive, because through it the result is the real scenario experienced by the company.

Another question that can be raised is in relation to the results found by Garcia, Lustosa and Barros (2010) and Matias (2006), since both works had smaller amounts of observations and simulations, which raises doubts if the application of other methodologies would not be more accurate and with more significant results. 
On the other hand, the argument of Donatelli and Korath (2005) and Fernandes (2005) is confirmed, since the biggest monthly error estimated by the Monte Carlo occurred in August with a lower forecast of "818,516" units. The authors of this work credit this result to the smaller amount of observations (time series) applied in the analysis, this confirms the proposed statement that the larger the sample number the smaller the standard deviation and the more accurate the result.

\section{CONCLUSION}

Based on all this information, it can be considered as the best methods to be applied in the forecast of demand, specifically in this company, the Weighted Moving Average and Moving Average methods, because they obtained results with a smaller average perceptual error obtaining a probability of correctness of $94 \%$.

In this way, it can be concluded that this article reached the objective of comparing time-series methods with Monte Carlo simulation and defining the best method for application in a mechanical component manufacturer.

It should be noted that this work is limited in relation to other comparisons and studies made earlier between different forecasting methods, mainly due to the limited amount of observations. It is important to mention that this study contributes with quantitative and qualitative information in the areas of management, logistics, planning and administration with theoretical content and veridical results that can be used not only as benchmarking but as cases for academic studies.

As an alternative for future work, we suggest new studies comparing different prediction methods, mainly using the Monte Carlo simulation.

\section{REFERENCES}

ARENALES, M.; et al. (2015) Pesquisa operacional para cursos de engenharia. $2^{\text {a }}$ Ed. Rio de Janeiro: Elsevier.

ARMSTRONG, J. S. (Ed.). (2001) Principles of forecasting: a handbook for researchers and practitioners. 1st Ed. New York. Springer Science \& Business Media.

CHOPRA, S.; MEINDL, P. (2003) Gerenciamento da Cadeia de Suprimentos:

Estratégia, Planejamento, e Operação. São Paulo: Cengage Learning.

DAVIS, M. M.; CHASE, R. B.; AQUILANO, N. J. (2001) Fundamentos da administração da produção. $3^{a} \mathrm{Ed}$. São Paulo: Bookman.

DONATELLI, G. D.; KONRATH, A. C. (2005) Simulação de Monte Carlo na avaliação de incertezas de medição. Revista de Ciência e Tecnologia, v. 13, n. 5. 
FERNANDES, CAB de A. (2005) Gerenciamento de riscos em projetos: como usar o Microsoft Excel para realizar a simulação Monte Carlo. Fundação Getúlio Vargas.

GARCIA, S.; LUSTOSA, P. R. B.; BARROS, N. R. (2010) Aplicabilidade do método de simulação de Monte Carlo na previsão dos custos de produção de companhias industriais: o caso da Companhia Vale do Rio Doce, Revista de Contabilidade e Organizações, v. 4, n. 10, p. 152-173.

HAACK, V. O.; RODRIGUES, J. T. M. C. (2018) Previsão de demanda. ENPEXSalão de Ensino, Pesquisa e Extensão do IFRS Campus Canoas, v. 1, n. 7.

HAIR, J. F.; et al. (2009) Multivariate data analysis with readings. Macmillan Publishing Company.1st Ed New York.

HARREL, C.; GHOSH, B. K.; BOWDEN, R. O. (2004) Simulation using Promodel. 2th Ed. MacGrawhill.

HEIZER, J.; RENDER, B. (2004) Operations management. $7^{\text {a }}$ ed. Upper Saddle River, NJ: Pearson Education.

HELENE, O. (2006) Métodos dos Mínimos Quadrados. $1^{\text {a }}$ Ed. São Paulo. Editora Livraria da Física.

LEMOS, F. O. (2006) Metodologia para seleção de métodos de previsão de demanda. Dissertação de M.Sc., UFRGS, Porto Alegre, RS.

MAKRIDAKIS, S. (1989) Why combining works? International Journal of Forecasting, v. 5, p. 601-603.

MATIAS JR., R. (2006) Análise quantitativa de risco baseada no método de Monte Carlo: abordagem PMBOK. In: I Congresso Brasileiro de Gerenciamento de Projetos-Florianópolis.

MCKENNA, R. (2005) Marketing de relacionamento. Rio de Janeiro: Elsevier.

MENDES, A. S.; SILVA, A. M.; KAWAMOTO JUNIOR, L. T. (2016) Balance capacity with variability caused by human factor: An application in a line with monte carlo simulation. Independent Journal of Management \& Production, v. 7, p. 627-642.

MOREIRA, D. M. (2001) Administração da produção e operações. $1^{a} \mathrm{Ed}$. Curitiba. Pioneira Thomson Learning.

MORETTIN, P. A; TOLOI, C. M. C. (1987) Previsão de séries temporais. $2^{\mathrm{a}}$ ed. São Paulo: Atual editora.

PELLEGRINI, F. R.; FOGLIATTO, F. S. (2001) Passos para implantação de sistemas de previsão de demanda: técnicas e estudo de caso. Production, v. 11, n. 1, p. 43-64.

SEVERINO, A. J. (2017) Metodologia do trabalho científico. 24a Ed. São Paulo Cortez editora.

TUBINO, D. F. (2009) Planejamento e controle da produção: teoria e prática. $2^{\mathrm{a}}$ Ed. São Paulo. Atlas.

WERNER, L.; RIBEIRO, J. L. D. (2006) Modelo composto para prever demanda através da integração de previsões. Production, v. 16, n. 3, p. 493-509, 2006. 